\title{
Application of SEM/EDS to environmental geochemistry of heavy metals
}

\author{
Uporaba SEM/EDS v okoljski geokemiji težkih kovin
}

\author{
Miloš MILER \& Mateja GOSAR \\ Geological Survey of Slovenia, Dimičeva ul. 14, SI-1000 Ljubljana, Slovenia; \\ e-mail: milos.miler@geo-zs.si; mateja.gosar@geo-zs.si
}

Prejeto / Received 20. 3. 2009; Sprejeto / Accepted 23. 4. 2009

Key words: environmental geochemistry, heavy metals, mining, smelting, SEM/EDS, sediments, mining waste dumps, environmental risk, pollution, environment

Ključne besede: geokemija okolja, težke kovine, rudarjenje, metalurgija, SEM/EDS, sedimenti, rudarski odpadki, okoljsko tveganje, onesnaženje, okolje

\begin{abstract}
Heavy metals represent a ubiquitous constituent of the near-surface environment, present in widely varying concentrations that typically have little impact on human behaviour and health. However, the mining of metals and use of these metals in industrial processes has produced significant anthropogenic inputs of metals to both local and global environments. As such, a rigorous overview of the current accumulation of heavy metals and knowledge of mineralogy of heavy metal-bearing phases is important for understanding their stability, solubility, mobility, bioavailability and toxicity. These data are of fundamental importance for environmental risk assessment and evaluation of future scenarios. Since conventional geochemical analyses provide limited information, other analytical methods have to be utilized for the characterisation of heavy metal-bearing phases. Significant analytical method for identification and characterisation of heavy metals in environmental media is a scanning electron microscope coupled with energy dispersive X-ray spectrometer (SEM/EDS), an apparatus for qualitative and semi-quantitative chemical analysis at microne level, newly introduced to Geological Survey of Slovenia. Use of SEM/EDS was already introduced to environmental studies world-wide. In Slovenia, SEM/EDS analyses of environmental media were firstly carried out on the Meža River stream sediments and snow deposits from Ljubljana urban area.

Heavy metal-bearing phases in the Meža River stream sediments were apportioned to three source areas: Mežica mining/smelting area (geogenic-technogenic origin), Ravne ironworks area (technogenic origin) and the Meža River catchment area (geogenic origin), which corresponds to data obtained by conventional geochemical and multivariate statistical methods.

Airborne particles, identified in urban snow deposits, were interpreted as geogenic particles, represented by fragments of heavy metal-bearing minerals, and technogenic particles that originate from combustion of solid and liquid fuels, iron and steel melting processes and road traffic emissions.

SEM/EDS proved to be a very useful analytical method for the study of heavy metal-bearing phases and characterisation according to their sources and genesis.
\end{abstract}

\section{Izvleček}

Težke kovine predstavljajo naravno navzoče sestavine v Zemljini skorji in na njeni površini, prisotne v zelo različnih koncentracijah. V splošnem imajo majhen vpliv na zdravje človeka. Rudarjenje teh kovin in njihova uporaba $\mathrm{v}$ industriji pomembno prispevajo k antropogenemu vnosu kovin v okolje. Natančen pregled obstoječih nakopičenj težkih kovin v naravnih okoljih in poznavanje mineralnih faz, ki vsebujejo težke kovine je zatorej bistvenega pomena za opredelitev njihove stabilnosti, topnosti, mobilnosti, dostopnosti za živa bitja in toksičnosti ter za oceno tveganja in napoved možnih scenarijev v prihodnosti. Ker običajne geokemične metode nudijo le omejene informacije, je potrebno za opredelitev faz težkih kovin uporabiti druge analitične metode. Pomembna metoda za prepoznavanje in opredelitev težkih kovin v okolju je vrstični elektronski mikroskop z energijsko disperzijskim spektrometrom rentgenskih žarkov (SEM/EDS), naprava za kvalitativno in semi-kvantitativno kemijsko analizo na mikronskem nivoju, ki je bila pred kratkim vpeljana tudi na Geološki zavod Slovenije. Uporaba SEM/EDS v okoljskih študijah je v svetu že dobro uveljavljena. V Sloveniji so bile prve analize okoljskih medijev s SEM/EDS izvedene na rečnih sedimentih reke Meže in snežnih depozitih urbanega območja Ljubljane, kar podajamo v tem prispevku.

$\mathrm{V}$ sedimentih reke Meže so bila določena tri izvorna območja težkih kovin: območje rudarjenja in predelave svinčevo-cinkove rude v Mežici (geogeno-tehnogeni izvor), območje železarne Ravne (tehnogeni izvor) in porečje reke Meže (geogeni izvor), kar se ujema z rezultati običajnih geokemičnih in multivariatnih statističnih metod.

Trdni delci v snegu urbanega okolja pripadajo geogenim delcem, ki jih predstavljajo drobci mineralov s težkimi kovinami, in tehnogenim delcem, ki izvirajo iz procesov izgorevanja trdnih in tekočih goriv, taljenja železa in obdelave jekel ter emisij prometa.

SEM/EDS se je izkazal kot zelo uporabna analitična metoda za proučevanje faz težkih kovin in za njihovo opredelitev glede na njihov izvor in nastanek. 


\section{Introduction}

Contamination of the Earth's ecosystems by potentially toxic metals is a global problem. It will probably grow with our planet's increasing population and their requirements for natural resources. Environmental geochemistry is the discipline that uses the chemistry of the solid earth, its aqueous and gaseous components, and life forms to assess contamination impacts on our planet's ecosystems (Siegel, 2002; Albarde, 2003). Environmental geochẻmical data identify pristine chemical conditions that pose no threats to ecosystem inhabitants, those that may suffer from natural sources (rock weathering and decomposition) and environments that are at risk from pollution as a result of human activities. Identifying metal loadings between natural and anthropogenic sources is in focus of geochemical studies as chemical damage to the environment often originates from a combination of natural and anthropogenic input. The type and speciation of an individual heavy metal determines its mobility between environmental media and its availability to organisms. Because of ecotoxicological effects of heavy metals, it is important to study the pathways of heavy metals into ecosystem and living organisms, their bioavailability, bioaccumulation, and general health effects.

Heavy metals represent a ubiquitous constituent of the near-surface environment, present in widely varying concentrations that typically have little impact on human behaviour and health. However, there are several sources of metals in the environment, both natural and manmade, thus localized enrichments of metals often result in elevated metal concentrations in the surrounding environment. The natural sources of metals in environment lie with the rocks and processes by which they formed and which affected them after lithification. High values of metals are found, for example, in mineralized areas and in areas where the dominant bedrock is rich in metals as, for example, in black shale. Volcanic emissions and forest fires are natural springs of some metals in the atmosphere (gases, aerosols, particulates) and after they precipitate they become part of the near-surface ecosystems. There are many anthropogenic sources in the environment: coal combustion residues, mining, metal-smelting industries, car emissions, military actions (PIRC \& BudKovič, 1996; GREIčIŪTÉ et al., 2007; IDZELIS et al., 2006) and primary input sources in agro-ecosystems (fertilizers, liming materials, sewage sludges, pesticides, irrigation water) (ADRIANo, 1986).

The mining and metal industry can be an important source of trace elements in the environment from (a) the mining and milling operations with problems of grinding, concentrating and transporting ores, and disposal of tails along with mine and mill waste water and (b) the smelter-refinery process with problems of concentrate, haulage, storage, sintering, atmospheric discharges and blowing dust (Adriano, 1986; Dudka \& Adriano, 1997; Jordan, 2009). The proportion of trace elements releases into environment depends on ores being processed. Mining itself affects relatively small areas. It is the tailings and waste rock deposits close to the mining area that are the source of the metals (Hoskin et al., 2000). The impacts of atmospheric discharges (gaseous and particulate matter emissions) from smelters can be detected within several kilometres from the point of release. Natural background contamination, often present in mining areas due to underlying mineralisation, adds to the complexity of the environmental assessment of contamination at mining sites. Knowledge of the mineralogy of heavy metal-bearing phases is important in understanding their stability, solubility, mobility, bioavailability and toxicity, modelling their future behaviour; and developing remediation strategies (HudsonEDWARDS, 2003).

One of the roles of environmental geochemistry is to scientifically evaluate how to manage metals at sources or in-situ so as to alleviate or eliminate their negative health impacts on living population. This is initiated by identifying pollution sources and by developing models of pollutant transport in different environmental media and by studying mobilization, interaction, deposition and accumulation of potentially toxic metals in source system and our planet's ecosystem.

Scanning electron microscope coupled with energy dispersive X-ray spectrometer (SEM/EDS) is an apparatus for qualitative and semi-quantitative chemical analysis at microne level, introduced to Geological Survey of Slovenia (GeoZS) in 2008. This analytical method was recently implicated into environmental researches of heavy metal-polluted environmental media in Slovenia. SEM/EDS microanalysis opened a new field of research in geochemistry and environmental geology in Slovenia, since no researches related to application of SEM/EDS to environmental studies of heavy metal pollution have been reported yet. Main contribution of the method is characterisation of heavy metal-bearing phases that represent primary potential pollutants in environmental media, according to their sources. Source apportionment is very important for localization of pollution sources and ascertainment of the degree of negative impacts, arising from individual heavy metal sources, natural and anthropogenic. Since conventional geochemical analyses, using sequential extraction preparation methods, provide limited information on mineralogy of heavy metal-bearing phases, SEM/EDS is very important for the assessment of bioavailability of heavy metals from heavy metal-bearing phases, according to chemical and physical properties of mineral species of these phases (Hudson-EDwards, 2003).

\section{Basic principles of SEM/EDS and identification of heavy metal-bearing phases}

Basically, electron microscope employs a beam of electrons and exploits the wavelike properties of electrons to obtain an image. Scanning electron microscope, employed at GeoZS, contains electron 
source of tungsten wire filament, which is heated to emit electrons that are accelerated by an anode. The electron beam diameter is regulated by electromagnetic condenser lenses and focused by objective lens into a probe point on the surface of the specimen (Goldstein et al., 2003; SAMARdžIJA, 2004; Zhou et al., 2006). Since the wavelength of the electron beam is much lower than that of visible light, resolution and useful magnification of SEM are much higher. Scanning coils move probe spot across specimen surface to form specimen image (Fig. 1).

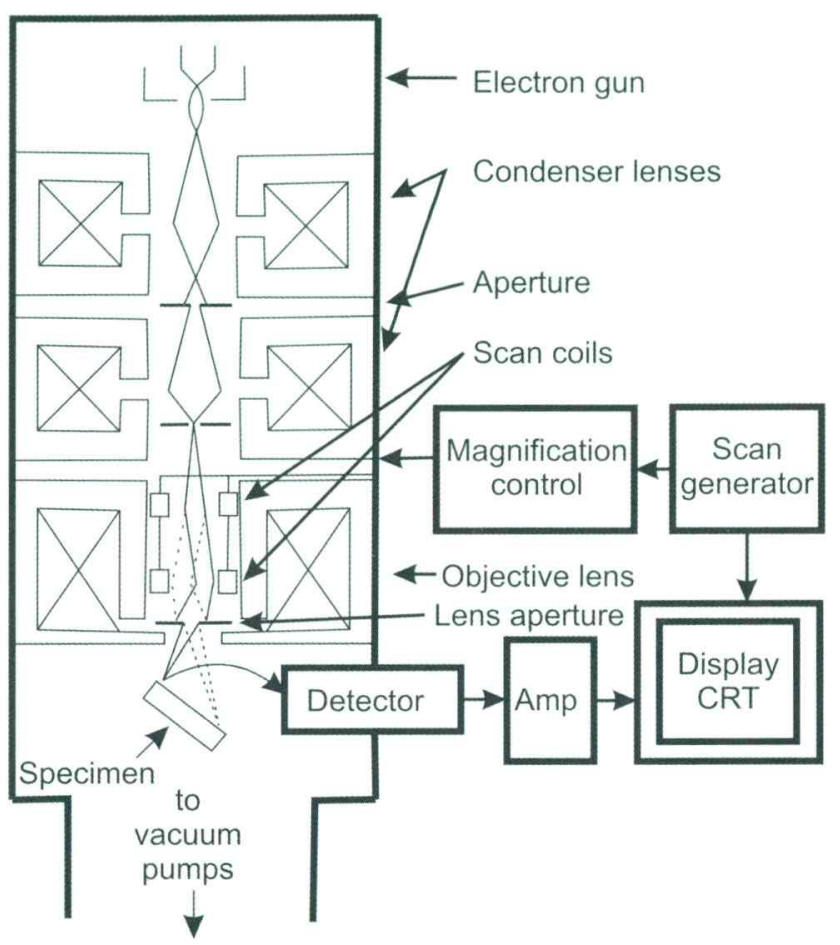

Fig. 1. Scheme of SEM and its operation (after GoLdsTEIN et al., 2003)

Sl. 1. Shema zgradbe SEM in njegovo delovanje (po GoLDSTEIN et al., 2003)

Interaction of electron beam with sample generates a variety of signals (secondary electrons (SE), backscattered electrons (BSE), characteristic $\mathrm{X}$-rays, etc.). SE are low energy electrons generated near the specimen surface as a result of excitation of loosely bound outer-shell electrons and form topographic image of sample. BSE are those primary beam electrons that were strongly deflected by atomic nuclei in the sample, retaining most of their energy after leaving the sample (GoLDSTEIN et al., 2003), and thus forming compositional or Z-contrast image of the sample. Characteristic $\mathrm{X}$-rays are generated deep in the sample as a result of interaction of electron beam with inner shell electron that is ejected and substituted with an electron from higher energy shell, emitting a photon of characteristic X-rays. Signals are detected by different detectors (scintillator (E-T) SE detector, semi-conductor BSE detector and semiconductor EDS detector) that transform signals into image or characteristic X-ray spectra.

One of main chemical characteristics of chemical elements is their atomic number (Z), which is unique for each element and is a basis for BSE imaging and X-ray (EDS) identification of heavy metal-bearing phases. The number of BSE is controlled by the atomic number of elements composing the sample. Elements with higher $\mathrm{Z}$ reflect more BSE than elements with lower Z, thus producing the so called Z-contrast or compositional contrast, which enables relative distinction between particles with different elemental composition. Heavy metals are electron dense elements with high atomic number and are effective electron backscatters.

Basic principles of heavy metal identification and characterisation are following. Firstly, the sample is examined in the backscattered electron (BSE) mode at low magnifications (Fig. 2) that allows localization of grains containing heavy metal-bearing phases in the sample (HochelLa et al., 2005). They appear bright in a low $\mathrm{Z}$ matrix (BERNAUs et al., 2005; AraGon et al., 2000).

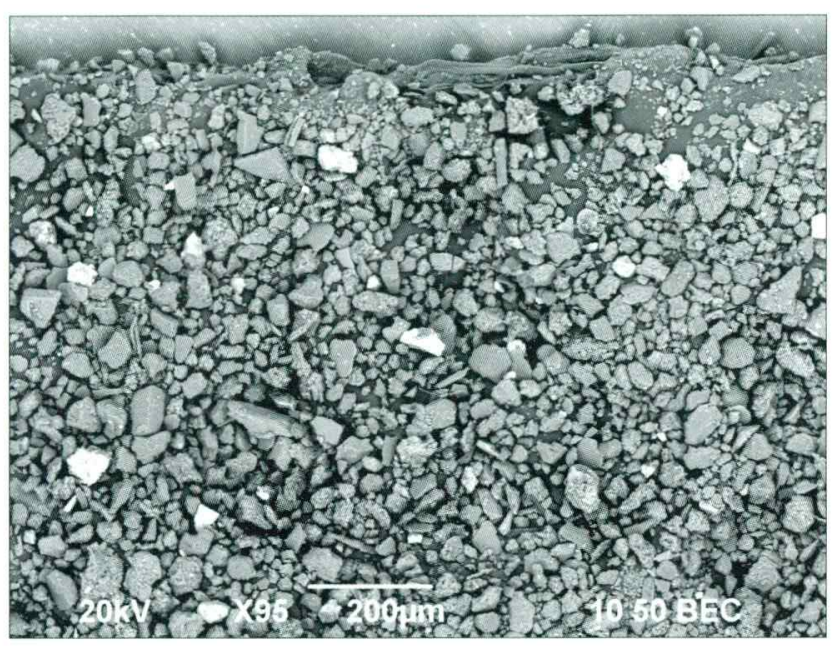

Fig. 2. Localization of heavy metal-bearing grains in BSE mode at low magnification

Sl. 2. Lociranje zrn, ki vsebujejo težke kovine v BSE načinu pri majhni povečavi

After localization of heavy metal-bearing grains in the sample with BSE imaging, qualitative and semi-quantitative chemical composition of selected grains is measured using energy dispersive X-ray spectrometer (EDS). EDS detects and processes $\mathrm{X}$-rays that are emitted from constituent elements and are characteristic of each chemical element, dependent on its atomic number.

Combination of SEM and EDS is used for single particle analysis. It enables the detection of heavy metals whose contents, determined by conventional geochemical bulk sample analysis, are below the theoretical detection limit of the EDS. Detection of some metal trace elements are thus possible. Mineral phases of heavy metals are then assessed from atomic proportions of constituent elements, obtained by semi-quantitative X-ray microanalysis. High resolution of scanning electron microscope allows analysis of heavy metals in wide range of environmental media (from mining waste deposits, stream sediments and soils to urban sediments and atmospheric depositions in snow). 


\section{World-wide experiences of using SEM/EDS in environmental geochemistry studies of heavy metals}

Characterisation of heavy metal-bearing pollutants in environmental media using SEM/EDS method was already successfully introduced to environmental studies world-wide. TRIMBACHER and Weiss (1999) investigated spruce needle surface characteristics and element contents. Heavy metal-bearing dust particles were detected only on needles from sites near pollutant sources. This method was used for characterisation and differentiation of areas with different pollution sources and levels (Trimbacher \& Weiss, 2004). Aragon and co-authors (2000) classified individual particles of heavy metal-bearing urban aerosols, according to their chemical or mineralogical composition and morphology, into different groups by their origin. Hudson-EDWARDS (2003) reviewed the literature on the sources, mineralogy, chemistry and fate of heavy metal-bearing particles in miningaffected river systems and geochemical and mineralogical techniques, employed for characterisation of heavy metal-bearing particles, including SEM/EDS. KEMPPAINEN and co-authors (2003) studied the distribution of airborne particles in the surroundings of an iron and steel factory in southern Finland and identified different particle types. JEONG and MCDOweLL (2003) distinguished different sources of stream sediments from the Southern Central Lake Superior using SEM/EDS. Hochella and co-authors (2005) observed heavy metal-mineral associations in stream and floodplain sediment samples and established that the source of floodplain material are mine tailings and smelter wastes. Bernaus and co-authors (2005) used the combination of SEM/EDS in order to evaluate the elemental background of ore, slag and soil samples from Almaden mercury mining area, while acquiring qualitative information on the chemical speciation of $\mathrm{Hg}$-rich particles. SEM/EDS analyses of mercury and arsenic contaminated soils, calcines and tailings derived from $\mathrm{Sb}-\mathrm{Hg}$ mineral deposit of the Valle del Azogue mine, confirmed that cinnabar, found in contaminated samples, is a secondary phase, precipitated after dissolution of $\mathrm{Hg}$-rich pyrite (NAVARRo et al., 2006). VANEK and co-authors (2008) studied the binding of metallic contaminants on soil constituents in contaminated alluvial soil from the mining and smelting district of Prúbram using a combination of mineralogical and chemical methods.

\section{PLATE 1 - TABLA 1}

1 Cerussite grain (arrow) associated with dolomite (polished section)

Zrno cerusita (puščica) v združbi z dolomitom (poliran obrus)

2 Galena with inclusions of dolomite

Galenit z vključki dolomita

3 Sphalerite grain, showing triangular pitting on its surface, caused by plucking or mineral dissolution

Zrno sfalerita s trikotnimi vdolbinami na površini, ki so posledica izpadanja materiala ali raztapljanja minerala

4 Smithsonite particle, containing minor amounts of $\mathrm{Cd}$

Zrno smithsonita z manjšo vsebnostjo $\mathrm{Cd}$

5 Descloizite crystal $\left(\mathrm{PbZn}\left(\mathrm{VO}_{4}\right)(\mathrm{OH})\right)$

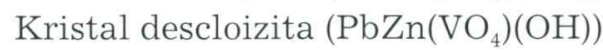

6 Octahedral crystal of ( $\mathrm{Pb}, \mathrm{Sb}$ )-oxide (arrow), presumably mineral bindheimite, associated with (Ca, Sb, Fe)-oxide

Oktaedrični kristal ( $\mathrm{Pb}, \mathrm{Sb}$ )-oksida (puščica), verjetno mineral bindheimit, v združbi

z ( $\mathrm{Ca}, \mathrm{Sb}, \mathrm{Fe})$-oksidom

7 (Cu, Ni, Fe)-alloy (polished section)

$(\mathrm{Cu}, \mathrm{Ni}, \mathrm{Fe})$-zlitina (poliran obrus)

8 Particle of (Fe, Si)-alloy

Delec (Fe, Si)-zlitine

9 (Mo, W, V, Cr, Fe)-oxide (Sp. 1) and (W, Cr, Fe)-oxide (Sp. 2) (polished section)

(Mo, W, V, Cr, Fe)-oksid (Sp. 1) in (W, Cr, Fe)-oksid (Sp. 2) (poliran obrus) 
PLATE 1 - TABLA 1
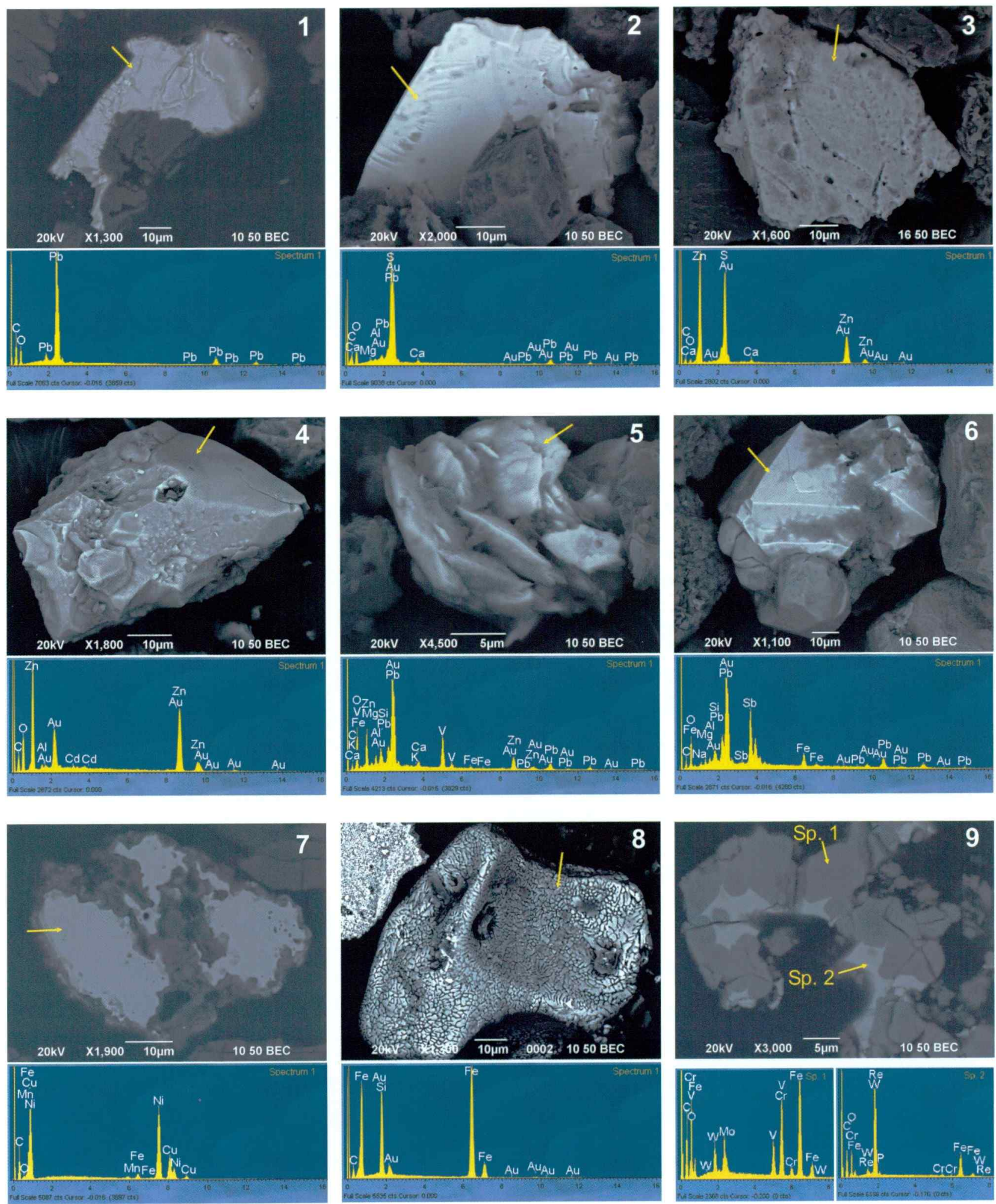


\section{Sample preparation and SEM/EDS analyses}

SEM/EDS analyses of different environmental media such as stream sediments, dust, solid snow deposits and aerosols require specific sample pretreatment. Proper sample preparation is thus one of the most critical steps in the SEM/EDS analysis.

Powdered samples of various environmental media are used for morphological studies and qualitative determination of mineral phases with $\mathrm{X}$-ray microanalysis. Since the emphasis of sediment or aerosol analysis is not on their texture and structure, their preparation is simple. Powdered samples are sprinkled on double-sided carbon tape, the excess removed with compressed air and coated with thin layer of conductive material, usually gold or carbon, to promote their conductivity.

For semi-quantitative X-ray microanalysis, flatpolished sections of analyzed materials are required. Observed particles are embedded in araldite resin, polished flat and coated with carbon. Gold usually provides better SE emission and conductivity of the sample than carbon, but considerably influences results of semi-quantitative X-ray microanalysis, because it absorbs characteristic $\mathrm{X}$-rays of lower $\mathrm{Z}$ elements and decreases intensities of their spectral lines. Therefore, carbon coating is usually used for semi-quantitative X-ray microanalyses on polished sections.
Regardless of sample preparation, some heavy metal-bearing mineral phases are difficult to distinguish from one another due to peak overlaps of X-ray spectral lines of constituent elements and limited resolution of the EDS.

Stream sediments and solid material in urban snow deposits were selected as representative environmental and sampling media for SEM/EDS analyses in present study. Stream sediments reflect rock structure of the catchment area, its geochemical characteristics and possible recent contamination upstream of the sampling point (OTTESEN et al., 1989). Snow represents natural collector and ideal medium for observation of dry or wet deposited atmospheric constituents, such as aerosol particles, which are well preserved in the snowcover as long as no melting occurs (ScHönER et al., 1997).

Stream sediment samples were oven-dried and sieved to the $<0,063 \mathrm{~mm}$ fraction. Both, powdered samples and polished sections were prepared. Snow samples were taken from surface of $1 \mathrm{~m}^{2}$ area, thawed at room temperature and filtered using medium fine filter paper. Snow particulate matter was extracted from filter paper to prepare powdered samples. Powdered samples of both materials were sputter-coated with gold and polished sections were coated with carbon. Samples were analyzed in high vacuum using BSE mode on JEOL JSM 6490LV SEM coupled with Oxford INCA Energy EDS at accelerating voltage $20 \mathrm{kV}$

\section{PLATE 2 - TABLE 2}

1 Technogenic spherical particle of dendritically crystallized (Cr, Fe)-oxide Tehnogeno sferično zrno dendritično kristaljenega ( $\mathrm{Cr}, \mathrm{Fe}$ )-oksida

2 Zircon crystal

Kristal cirkona

3 Monazite grain

Zrno monazita

4 Chalcopyrite (arrow) in pyroxene or amphibole (polished section)

Halkopirit (puščica) v piroksenu ali amfibolu (poliran obrus)

5 Xenotime $\left(\mathrm{YPO}_{4}\right.$ ) (arrow) in $\mathrm{K}$-feldspar or biotite

Xenotim $\left(\mathrm{YPO}_{4}\right)$ (puščica) v K-glinencu ali biotitu

6 Carbonaceous hollow spherical particle (low-temperature domestic combustion product)

Ogljikov votli sferični delec (nizkotemperaturna hišna kurišča)

7 Spherical particle of Ca-ferrite (high-temperature industrial coal combustion product) Sferični delec Ca-ferita (visokotemperaturni industrijski sežig premoga)

8 Heavy metal-bearing spherical particle of ( $\mathrm{Cr}, \mathrm{Ni}$ )-oxide (high-temperature iron and steel melting processes)

Sferični delec s težkimi kovinami, (Cr, Ni)-oksid (visokotemperaturno taljenje jekla in železa)

$9 \quad$ Irregularly shaped particle, interpreted as coal residue (coke)

Delec nepravilnih oblik, domnevno nezgoreni ostanek premoga (koks) 
PLATE 2 - TABLE 2
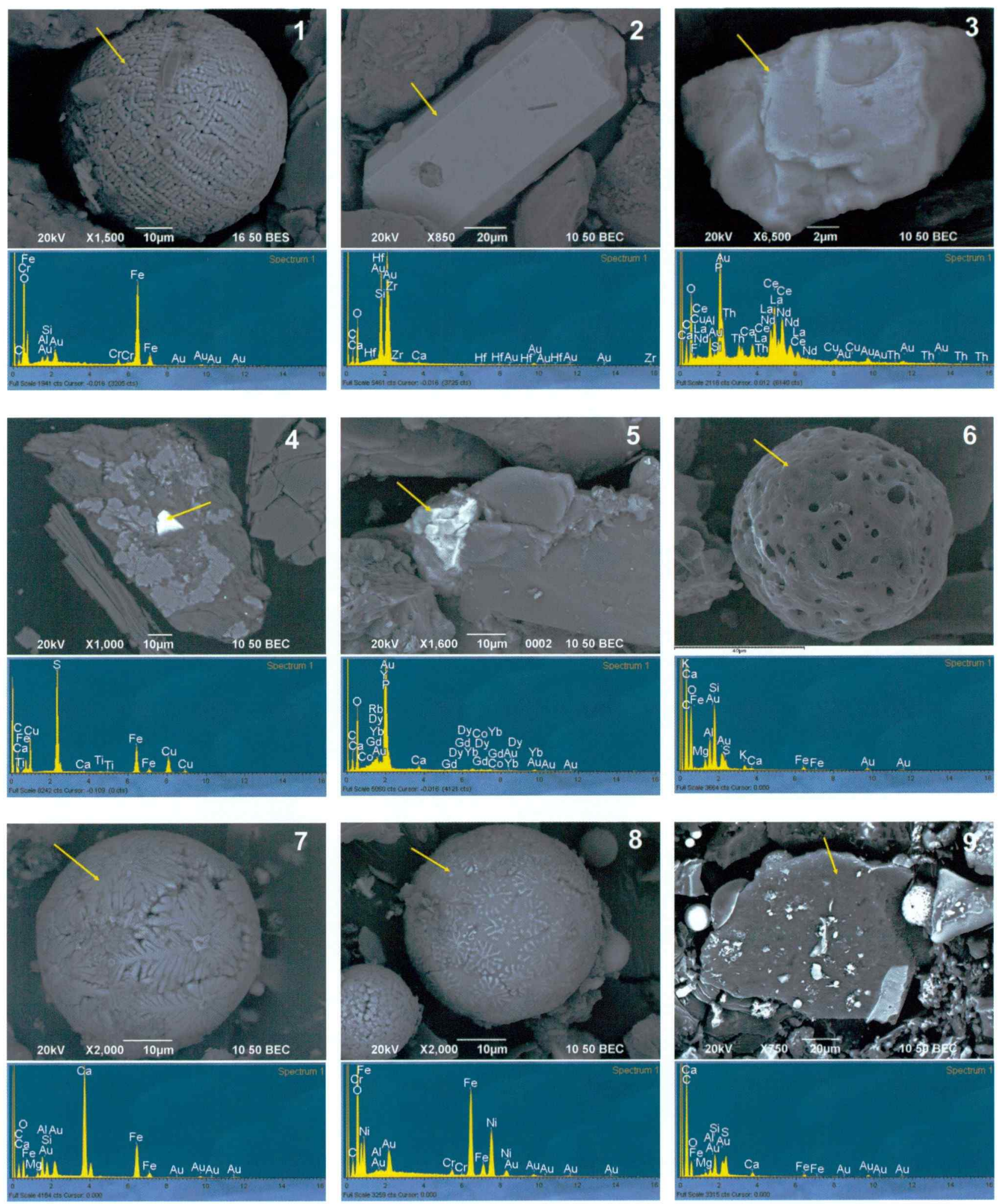
and working distance $10 \mathrm{~mm}$. Mineral phases of heavy metals were assessed from atomic proportions of constituent elements, obtained by semiquantitative X-ray microanalysis.

\section{Results and discussion}

\section{Stream sediments in Mežica mining area}

The environs of Mežica are strongly polluted with lead, zinc, arsenic, cadmium and molybdenum. Previous investigations of heavy metal pollution in the Meža valley have shown that the environment in the upper Meža valley is highly polluted (KugONIČ \& ZuPAN, 1999; VREčA et al., 2001; Bole et al., 2002; ŠAJN, 2006; Fux \& Gosar, 2007). ŠAJN (2006) demonstrated the spatial distribution of heavy metals in soil and based on the factor analysis he determined two natural geochemical associations that are a consequence of natural bedrock weathering, and two anthropogenic geochemical associations that are a consequence of mining/smelting and ironworks activities were determined in the Meža valley. Detailed analyses of stream sediments of the Meža River and its tributaries were carried out by BoLE and co-authors (2002) and Fux and Gosar (2007) who found out that, although the mining and metallurgical facilities have ceased to operate, their influence on stream sediments is still significant, due to washing out of heavy metal-contaminated material from mining and ore processing waste deposits into streams.

In the Meža valley we focused on identifying heavy metal-bearing phases in heavily polluted environmental media of Mežica mining district, characterising them according to their source and genesis and thus ascertain the degree of negative impacts arising from $\mathrm{Pb}-\mathrm{Zn}$ mining and smelting activities in the Mežica mining district and ironworks in Ravne area. Source apportionment and genesis of heavy metal-bearing phases in environmental media were carried out on basis of particle morphology and their elemental composition, greatly assisted by comparison with material from source areas (source material). Chemical composition of geogenic heavy metal-bearing mineral phases is relatively simple compared to technogenic phases that possess complex chemical composition (Aragon et al., 2000).

Samples of stream sediments, taken from the most polluted areas of the Meža Valley were analyzed using SEM/EDS. Detected heavy metals are $\mathrm{Pb}, \mathrm{Zn}, \mathrm{Cr}, \mathrm{Ni}, \mathrm{Mn}, \mathrm{Mo}, \mathrm{Cd}, \mathrm{Ti}, \mathrm{V}, \mathrm{W}, \mathrm{Zr}, \mathrm{Ce}, \mathrm{Sb}, \mathrm{Cu}$, $\mathrm{Y}, \mathrm{Sr}, \mathrm{Ba}$ and Ag, which appear in forms of different heavy metal-bearing phases.

In sediments of the Mežica mining and smelting area, mineral phases such as cerussite $\left(\mathrm{PbCO}_{3}\right)$ (Pl. 1, Fig. 1), galena (PbS) (Pl. 1, Fig. 2), sphalerite $(\mathrm{ZnS})\left(\mathrm{Pl} .1\right.$, Fig. 3), smithsonite $\left(\mathrm{ZnCO}_{3}\right)(\mathrm{Pl} .1$, Fig. 4), descloizite $\left(\mathrm{PbZn}\left(\mathrm{VO}_{4}\right)(\mathrm{OH})\right)(\mathrm{Pl}$ 1, Fig. 5), bindheimite $\left(\mathrm{Pb}_{2} \mathrm{Sb}_{2} \mathrm{O}_{6}(\mathrm{O}, \mathrm{OH})\right)(\mathrm{Pl} .1$, Fig. 6) and pyromorphite $\left(\mathrm{Pb}_{5}\left(\mathrm{PO}_{4}\right)_{3} \mathrm{Cl}\right)$ were identified. Their sources are geogenic and technogenic processes in the Mežica mining district.
Technogenic phases, such as various Fe-alloys ((Cr, Ni)-ferroalloy, (Cu, Ni)-alloy (Pl. 1, Fig. 7) and (Fe, Si)-alloy (Pl. 1, Fig. 8)), Fe-oxides ((Cr, V, Fe)-oxide, (Mo, W, V, Cr, Fe)-oxide (Pl. 1, Fig. 9), (Mo, W)-oxide, (W, Cr, Fe)-oxide (Pl. 1, Fig. 9)) and spherical particles ((Cr, Ni)-oxide-chrome-nickelspinel, (Cr, Fe)-oxide-ferrochrome-spinel (NeINAvAIE et al., 2000) (Pl. 2, Fig. 1)), were recognized in the area of Ravne ironworks.

Mineral phases of geogenic origin that were found in most of the investigated sediments in upper and lower Meža Valley are zircon $\left(\mathrm{ZrSiO}_{4}\right)$ (Pl. 2, Fig. 2), rutile $\left(\mathrm{TiO}_{2}\right)$, ilmenite $\left(\mathrm{FeTiO}_{3}\right)$, barite $\left(\mathrm{BaSO}_{4}\right)$, monazite $\left((\mathrm{Ce}, \mathrm{La}, \mathrm{Nd}) \mathrm{PO}_{4}\right)(\mathrm{Pl} .2$, Fig. 3), sphene $\left(\mathrm{CaTiSiO}_{5}\right)$, chalcopyrite $\left(\mathrm{CuFeS}_{2}\right)$ (Pl. 2, Fig. 4), xenotime $\left(\mathrm{YPO}_{4}\right)$ (Pl. 2, Fig. 5) and strontianite $\left(\mathrm{SrCO}_{3}\right)$. Most of geogenic mineral phases are common rock forming minerals, composing metamorphic, igneous and carbonate bedrock of the Meža River and tributary catchment areas. Their source is most probably weathering of bedrock in the catchment areas of the Meža River and its tributaries, which is indicated by associations of common rock-forming minerals in stream sediments and the fact that they are present in all samples, independently of sampling location.

\section{Snow deposit in Ljubljana urban area}

Preliminary analyses using SEM/EDS enabled characterisation and source apportionment of airborne particles deposited in snow. Geogenic and technogenic sources of those particles were determined according to their morphology and elemental composition.

Particles of geogenic origin are represented by fragments of heavy metal-bearing mineral phases, mostly as zircon, barite, pyrite and other rock-forming minerals.

Most of technogenic particles originate presumably from combustion processes and road traffic emissions (NEINAVAIE et al., 2000). Very porous hollow spherical particles (Pl. 2, Fig. 6) and irregularly shaped soot particles, composed mainly of $\mathrm{C}$ and $\mathrm{S}$ and partly $\mathrm{Ca}$ and $\mathrm{Fe}$, were interpreted as low-temperature domestic combustion products (domestic furnaces). Calcium and iron containing spherically shaped particles, designated as $\mathrm{Ca}-$ ferrites (Pl. 2, Fig. 7), and $\mathrm{Ca}, \mathrm{Al}$ and $\mathrm{Si}$ containing spherical particles, designated as (Ca, Al)-silicates, presumably emanate from high-temperature industrial coal combustion (coal-burning power plants). Spherically shaped heavy metal-bearing particles containing $\mathrm{Cr}$, Ni and Fe probably originate from high-temperature iron and steel melting processes (ironworks, steelworks). Such particles were interpreted as (Cr, Ni)-oxides-chrome-nickel spinels (Pl. 2, Fig. 8), (Cr, Fe)-oxides-ferrochrome spinels and ( $\mathrm{Ca}, \mathrm{Fe})$-silicates. Road traffic particles are generally represented by irregular particles that were interpreted as exhaust soot, tyre fragments, containing C, S, Ca and Fe, and steel fragments, consisting of $\mathrm{Cr}, \mathrm{Fe}$ and small amounts of Ti. Irregularly shaped particles, interpreted as coal residue (coke) (Pl. 2, Fig. 9), were also found. 


\section{Conclusions}

A combination of SEM and EDS proved to be a very useful analytical method for the study of heavy metal-bearing phases and characterisation according to their sources and genesis. Results of our SEM/EDS analyses of environmental media agree well with data obtained by conventional geochemical methods and provide supplemental information on species, morphology, sources and genesis of geogenic and anthropogenic heavy metal-bearing phases. Knowledge of mineralogy of heavy metal-bearing phases, obtained by SEMI/ EDS analysis, is important in understanding their stability, solubility, mobility, bioavailability, toxicity and developing remediation strategies.

Source apportionment and genesis of heavy metal-bearing phases in environmental media is greatly assisted by particle morphology, their elemental composition and comparison with source material. However, some of frequently occurring heavy metal-bearing mineral phases are difficult to distinguish from one another due to peak overlaps of X-ray spectral lines and limited resolution of the EDS. Such heavy metal-bearing mineral phases are $\mathrm{Pb}$-sulfides and $\mathrm{Pb}$-molybdates. SEM/ EDS also enables detection of heavy metals that represent major components of rarely occurring mineral phases in the sample. However, determination of heavy metals that represent trace elements in frequently occurring mineral phases is difficult and depends on their content.

\section{Acknowledgements}

Presented study was carried out in the frame of the research programme Groundwaters and geochemistry at Geological Survey of Slovenia. The authors would like to thank to the Slovenian Research Agency (ARRS) for financial support. We also thank to Dr. Hassan Neinavaie from Geological Survey of Austria (GBA) for useful suggestions and help with interpretation of SEM/EDS data.

\section{References}

Adriano, D. C. 1986: Trace elements in the terrestrial environment. Springer-Verlag (New York, Berlin, Heidelberg, Tokyo): 1-533.

Albarde, F. 2003: Geochemistry. Cambridge University Press (Cambridge): 1-248.

Aragon, A. P., Torres, G. V., Monroy, M. F., LuszCzewski, A. K. \& Leyva, R. R. 2000: Scanning electron microscope and statistical analysis of suspended heavy metal particles in San Luis Potosi, Mexico. Atmospheric Environment 34: 4103-4112.

Bernaus, A., Gaona, X. \& Valiente, M. 2005: Characterization of Almaden mercury mine environment by XAS techniques. J. Environ. Monit. 7: 771-777.

Bole, M., Druks, P., Rošer-Drev, A. \& Vetrih, M. 2002: Meža s pritoki - sediment, segment vode. In: Ribarič LASNIK C.: Primerjalna študi- ja o onesnaženosti okolja v Zg. Mežiški dolini med stanji v letih 1989 in 2001. Final report: $106-125$.

Dudka, S. \& Adriano, D. C. 1997: Environmental impacts of Metal Ore Mining and processing: A Review. Journal of Environmental Quality 2: 590-602.

Fux, J. \& Gosar, M. 2007: Vsebnosti svinca in drugih težkih kovin v sedimentih na območju Mežiške doline (Lead and other heavy metals in stream sediments in the area of Meža valley). Geologija (Ljubljana) 50/2: 347-360.

Goldstein, J., Newbury, D., Joy, D., Lyman, C., EchLin, P., Lifshin, E., Sawyer, L. \& Michael, J. R. 2003: Scanning electron microscopy and X-ray microanalysis, 3rd edition. Kluwer Academic/ Plenum Publishers (New York): 1-689.

Greičiūté K., Juozulynas A., Šurkiené G., \& VALEIKIENÉ, V. 2007: Research on soil disturbance and pollution with heavy metals in military grounds. Geologija (Ljubljana) 57: 14-20.

Hochella Jr, M., F., Moore, J. N., Putnis, C. V., Putnis, A., Kasama, T. \& EberL, D. D. 2005: Direct observation of heavy metal-mineral association from the Clark Fork River Superfund Complex: Implications for metal transport and bioavailability. Geochimica et Cosmochimica Acta 7/69: 1651-1663.

Hoskin, W., Bird, G. \& Stanley, T. 2000: Mining - facts, figures and environment. Industry and environment 23: 4-8.

Hudson-Edwards, K. A. 2003: Sources, mineralogy, chemistry and fate of heavy metal-bearing particles in mining-affected river systems. Mineral. Mag. 67: 205-217.

Idzelis, R., Greičiūté, K. \& Dainius, L. P. 2006 : Investigation and evaluation of surface water pollution with heavy metals and oil products in kairiai military ground territory. Journal of Environmental Engineering \& Landscape $\mathrm{Ma}-$ nagement 14/4: 183-190.

Jeong, J. \& McDowell, S. D. 2003: Characterization and Transport of Contaminated Sediments in the Southern Central Lake Superior. Journal of Minerals \& Materials Characterization \& Engineering 2/2: 111-135.

JoRDAN, G. 2009: Sustainable mineral resources management: from regional mineral resources exploration to spatial contamination risk assessment of mining. Environ. Geol., on line first: 17 pp.

Kemppainen, S., Tervahattu, H. \& Kikuchi, R. 2003: Distribution of airborne particles from multiemission source. Environmental Monitoring and Assessment 85: 99-113.

Kugonič, N. \& Zupan, M. 1999: Vsebnosti Pb, Cd in $\mathrm{Zn} \mathrm{v}$ tleh in nekaterih rastlinah $\mathrm{v}$ Zgornji mežiški dolini. In: RIBARIČ-LASNIK C. et al. (eds): Problem težkih kovin v Zgornji Mežiški dolini: proceedings volume, Environmental Research \& Industrial Co-operation Institute ERICo (Velenje): 66-78.

Navarro, A., Biester, H., Mendoza, J. L. \& CarDELlACH, E. 2006: Mercury speciation and mobilization in contaminated soils of the Valle del 
Azogue Hg mine (SE, Spain). Environ. Geol. 49: 1089-1101.

Neinavaie, H., Pirkl, H. \& Trimbacher, C. 2000 : Herkunft und Charakteristik von Stäuben: Research report. Umweltbundesamt (Wien): $1-61$.

Ottesen, R. T., Bogen, J., Bølviken, B. \& Volden, T. 1989: Overbank sediment: a representative sample medium for regional geochemical mapping. J. Geochem. Explor. 32: 257-277.

Pirc, S. \& Budkovič, T. 1996: Remains of World War 1 geochemical pollution in the landscape. In: Richardson, M. (ed.): Environmental xenobiotics. Taylor \& Francis (London): 375-418.

SAMARDŽIJA, Z. 2004: Osnove metod SEM in AFM za preiskave površin. Vakuumist (Ljubljana) 24/1-2: 4-12.

Schöner, W., Puxbaum, H., Staudinger, M., MaupeTIT, F. \& WagenBach, D. 1997: Spatial variability in the Chemical Composition of the Snowcover at High Alpine Sites. Theor. Appl. Climatol. 56: $25-32$.

Siegel, F. R. 2002: Environmental Geochemistry of Potentially Toxic Metals. Springer - Verlag (Berlin, Heidelberg): 1-218.

ŠAJN, R. 2006: Factor Analysis of Soil and Atticdust to Separate Mining and Metallurgy Influ- ence, Meža Valley, Slovenia. Mathematical Geology 38/6: 735-747.

Trimbacher, C. \& Weiss, P. 1999: Needle surface characteristics and element contents of Norway spruce in relation to the distance of emission sources. Environmental Pollution 105: 111-119.

Trimbacher, C. \& Weiss, P. 2004: Norway spruce: A novel method using surface characteristics and heavy metal concentrations of needles for a large-scale monitoring survey in Austria. Water, Air and Soil Pollution 152: 363-386.

Vanek, A., Ettler, V., Grygar, T., Boruvka, L., ŠeBeK, O. \& Draber, O. 2008: Combined chemical and mineralogical evidence for heavy metal binding in mining- and smelting-affected alluvial soils. Pedosphere 18/4: 464-478.

VReča, P., Pirc, S. \& Šajn, R. 2001: Natural and anthropogenic influences on geochemistry of soils in barren and mineralized carbonate terrains. Journal of Geochemical Exploration 74: 99-108.

Zhou, W., Apkarian, R. P., Wang, Z. L. \& Joy, D. 2006: Fundamentals of Scanning Electron Microscopy. In: Zhou, W. \& Wang, Z. L. (eds.): Scanning Microscopy for Nanotechnology, Techniques and Applications. Springer (New York): 1-40. 